\title{
UK FINANCIAL INSTITUTIONS AND MARKETS
}




\section{UK FINANCIAL INSTITUTIONS AND MARKETS}

MICHAEL PAWLEY

DAVID WINSTONE

PATRICK BENTLEY

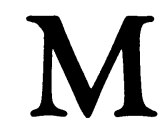

MACMILLAN 
(C) Michael Pawley, David Winstone and Patrick Bentley 1991

All rights reserved. No reproduction, copy or transmission of this publication may be made without written permission.

No paragraph of this publication may be reproduced, copied or transmitted save with written permission or in accordance with the provisions of the Copyright, Designs and Patents Act 1988, or under the terms of any licence permitting limited copying issued by the Copyright Licensing Agency, 90 Tottenham Court Road, London W1P 9HE.

Any person who does any unauthorised act in relation to this publication may be liable to criminal prosecution and civil claims for damages.

First published in 1991 by

MACMILLAN EDUCATION LTD

Houndmills, Basingstoke, Hampshire RG21 2XS

and London

Companies and representatives

throughout the world

ISBN 978-0-333-55536-1

ISBN 978-1-349-21660-4 (eBook)

DOI 10.1007/978-1-349-21660-4

A catalogue record for this book is available from the British Library.

Typeset and illustrated by

TecSet Ltd, Wallington, Surrey. 
For our parents 


\section{CONTENTS}

List of Figures

xii

List of Tables

xiv

1 Introduction

Michael Pawley

2 Financial Intermediation 6

Michael Pawley

2.0 Introduction

2.1 Financial Intermediation 6

2.2 Maturity Transformation 9

2.3 Risk Pooling 10

2.4 Aggregation of Savings 10

2.5 Reduction in Transactions Costs 11

2.6 Disintermediation 11

2.7 Flow of Funds 13

3 Interest Rates $\quad 19$

Michael Pawley

$\begin{array}{lll}3.0 & \text { Introduction } & 19\end{array}$

3.1 The Spectrum of Interest Rates 19

3.2 Nominal and Real Interest Rates 22

3.3 The General Level of Interest Rates 22

3.4 The Term Structure of Interest Rates 27

3.5 Theories of the Term Structure 29

4 The UK Banking Sector 31

David Winstone

4.0 Introduction 31

4.1 Banks 32 
4.2 Discount Houses 38

4.3 British Merchant Banks 39

4.4 Overseas Banks $\quad 40$

4.5 Prudential Supervision 40

4.6 Capital Adequacy, Bank Operations and Profitability 44

4.7 Bank Liquidity Requirements 44

4.8 Banking and Europe 1992

5 Building Societies $\quad 48$

Michael Pawley

5.0 Introduction 48

5.1 The Effect of the Cartel on Building Society 52 Operations

5.2 Competition $\quad 55$

5.3 Profits/Surplus $\quad 66$

5.4 Capital and Liquidity 69

$\begin{array}{lll}5.51992 & 71\end{array}$

6 Insurance $\quad 73$

Patrick Bentley

$\begin{array}{lll}6.0 & \text { Introduction } & 73\end{array}$

6.1 General Insurance $\quad 73$

6.2 Long Term Insurance $\quad 74$

6.3 Statutory Classification of Insurance 75

6.4 Insurance Suppliers $\quad 76$

6.5 The Need for Insurance 77

6.6 Factors Influencing the Price of Insurance 79

$\begin{array}{ll}6.7 \text { Profitability } & 81\end{array}$

6.8 Market Share $\quad 88$

6.9 Asset Portfolios 91

6.10 Reinsurance and Coinsurance 94

6.11 Supervision of Insurance $\quad 97$

6.12 EC and Insurance 101

6.13 Conclusion 103

7 Non-Bank Financial Intermediaries 105

Michael Pawley

$\begin{array}{lll}7.0 & \text { Introduction } & 105\end{array}$

$\begin{array}{lll}7.1 & \text { Unit Trusts } & 105\end{array}$ 
7.2 Investment Trusts 111

7.3 Pension Funds 117

7.4 Venture Capital 124

7.5 Finance Houses 128

7.6 National Savings 130

7.7 Various Schemes 132

8 The Bank of England 137

Michael Pawley

8.0 Introduction 137

8.1 Functions and Structure 137

8.2 Powers/Changing Role 146

8.3 Independence of the Bank of England 146

9 Sterling Money Markets $\quad 150$

David Winstone

9.0 Introduction 150

9.1 The Discount and Parallel Markets 151

9.2 Price/Yield Relationships of Financial 153 Instruments

9.3 Money Market Instruments 160

9.4 Treasury Bills-Institutional Arrangements 161

9.5 Certificates of Deposit 162

9.6 Bills of Exchange 164

9.7 Local Authority Market 169

9.8 Finance House Market 170

9.9 Sterling Inter-Bank Market 170

9.10 Central Money Markets Office 171

9.11 The Role of the Bank of England in the 172 Sterling Money Markets

9.12 Money Market Interest Rates and Base Rate $\quad 180$

9.13 Minimum Lending Rate 184

10 Euro-Currency 185

David Winstone

10.0 Definitions 185

10.1 Understanding Eurocurrency 187

10.2 Eurocurrency and Credit Creation 190

10.3 Eurocurrency Statistics 194

10.4 Pattern of Activity in the Eurocurrency Market 194 
10.5 Eurocurrency Interest Rates and Forward Exchange Rates

11 The Stock Exchange

Michael Pawley

11.0 Introduction 203

11.1 The Role of the Stock Exchange 203

11.2 Big Bang 205

11.3 Issue Costs 208

11.4 Breadth and Depth 212

11.5 Spreads and Turnover 213

11.6 Recent Developments: Dealing Changes 219

11.7 Settlement Procedures 220

11.8 The 1987 Crash and Market Efficiency 221

11.9 Stock Market Regulation 226

11.10 Insider Dealing 227

11.11 Prudential Regulation $\quad 228$

11.12 Takeover Regulation $\quad 229$

11.13 Overseas/European Competition 230

11.14 The Gilt-Edged Market 232

12 The Regulatory Framework 235

Michael Pawley

$\begin{array}{lll}12.0 & \text { Introduction } & 235\end{array}$

12.1 The Need for Regulation 235

12.2 Investor Protection 239

12.3 Over-Regulation? 243

12.4 The Core Rules 252

12.5 Prudential Regulation 254

12.6 Systemic Risk 256

12.7 Harmonisation of European Regulation 259

13 Current Issues/Trends $\quad 264$

Michael Pawley

13.0 Introduction 264

13.1 Conglomeration 264

$\begin{array}{lll}13.2 & \text { Securitisation } & 270\end{array}$

13.3 Globalisation 273 
Contents xi

13.41992

275

13.5 Financial Innovation

285

13.6 Short Termism

290

Index

296 


\section{LIST OF FIGURES}

2.1 Financial intermediation 7

2.2 The risk/return trade-off $\quad 8$

2.3 Disintermediation - inter-company market 11

2.4 Disintermediation - pre-Big Bang 12

2.5 Disintermediation - post-Big Bang 12

2.6 Financial intermediation and flow of funds 12

3.1 Loanable funds 23

3.2 Loanable funds: excess supply 24

3.3 Loanable funds: excess demand 24

3.4 Liquidity preference theory 26

3.5 Liquidity preference theory: a fall in the supply of 26 money

3.6 Representative yield curves (gilts) 28

3.7 Yield curves and expectations 28

5.1 Effect of the cartel on mortgage supply 54

8.1 Organisation of the Bank of England 138

9.1 Treasury bill prices 157

9.2 Treasury bill prices following a change in yield 158

9.3 Creation of a bill of exchange 165

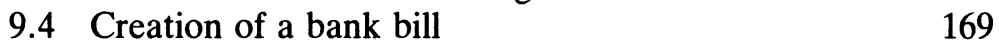

9.5 Liquidity Adjustment, closed economy 175

9.6 Liquidity Adjustment, open economy 175

11.1 Commission rates 1980-9 215

11.2 Average best touch 1987-9 216

11.3 UK equity average daily turnover customer business 218 1965-89 222

11.4 Settlement procedure (stylised)

12.1 Regulation (simplified) 238

12.2 Evolution of the Financial Services Act 239

12.3 Investor protection framework 244

12.4 Regulators framework (simplified) 245 
13.1 Off and on-balance sheet banking 271

13.2 Globalisation of financial markets 273

13.3 Competitive matrix $1992 \quad 283$

13.4 Competitive matrix $1992 \quad 284$

13.5 Financial innovation 286

13.6 A 'classical' swap 289 


\section{LIST OF TABLES}

2.1 Personal sector financial transactions 14

2.2 Selected transactions of industrial and commercial 15 companies

2.3 Other financial institutions' sources and uses of 16 funds

2.4 Selected overseas sector financial transactions 17

4.1 The UK banking sector 31

4.2 Deposit balances end-June 1990 of groups of 32 institutions within UK banking sector

4.3 Retail banks 33

4.4 Balance sheet (selected items) banks in the UK 34

4.5 Lloyds, Natwest, Barclays, Midland 38

4.6 Members of the London Discount Market 39 Association

5.1 Building societies' assets and liabilities 49

5.2 Loans for house purchase 50

5.3 Personal sector liquid assets 51

5.4 Building societies: progress 52

5.5 Regulatory matrix for banks and building societies 58 1974

5.6 Building society retail and wholesale funding 61

5.7 Regulatory matrix for banks and building societies 63 1980

5.8 Market share of personal sector liquid assets $\quad 65$

5.9 Loans for house purchase: market share 66

5.10 Minimum acceptable capital ratios 70

6.1 Statutory classification of insurance 75

6.2 Overall trading profit of world-wide general 82 insurance $\mathrm{ABI}$ member companies

6.3 Non-life underwriting losses $\quad 82$

6.4 Companies' investment income $\quad 84$

6.5 Lloyds' capacity and profits 85 
$\begin{array}{lll}6.6 & \text { Lloyds' profitability by class } & 87\end{array}$

$\begin{array}{lll}6.7 & \text { Lloyds' global accounts 31.12.84 } & 89\end{array}$

6.8 Largest UK companies' world-wide premium $\quad 89$ income

6.9 Proportion of all company premiums controlled by 90 largest companies

6.10 Investments life and general insurance 1988-9 ABI 92 member companies

6.11 Sample of life reinsurers premium incomes 97

$\begin{array}{lll}7.1 & \text { Unit trust industry statistics } & 108\end{array}$

7.2 UK unit trusts: assets and liabilities 109

7.3 UK unit trusts: asset distribution holdings 110

7.4 UK property unit trusts: aggregate assets $\quad 110$

$\begin{array}{lll}7.5 & \text { Investment trusts: aggregate assets } & 113\end{array}$

7.6 Investment trusts' asset distribution 114

7.7 UK investment trusts: medium and long-term 115 liabilities and capital

$\begin{array}{lll}7.8 & \text { UK pension funds: assets portfolio holdings } & 120\end{array}$

7.9 Selected asset holdings of pension funds 121

7.10 UK pension funds: analysis by type of fund 122

7.11 Venture capital investment in the UK (numbers) 126

7.12 Venture capital in the UK (amount) 127

7.13 Non-bank credit companies: aggregate balance 131 sheet

7.14 National Savings 133

8.1 Assets and liabilities of the Bank of England 139

9.1 Discount market and parallel market 152

9.2 Treasury Bill prices according to maturity 156

9.3 Calculation of new Treasury bill prices following a 159 change in yield

11.1 Total sums raised via initial public offers 209

11.2 Initial public offers 1985-9 210

11.3 Direct costs of initial public offers 210

11.4 Admission requirements for ISE markets 211

11.5 Average spreads 217

11.6 History of UK equity market makers 217

11.7 Financial results of all ISE member firms 219

11.8 International market statistics 231

11.9 Share classifications 233

13.1 Percentage differences in prices of standard 276-277 final products in EC 